\title{
Efektivitas Kebijakan Daerah dalam Penurunan Angka Kematian Ibu dan Bayi
}

\author{
Effectiveness Analysis of Local Policies in Reducing Maternal and Infant \\ Mortality
}

\author{
Wiko Saputra, Victoria Fanggidae, Ah Mafthuchan
}

\section{Perkumpulan Prakarsa Indonesia}

\begin{abstract}
Abstrak
Di Indonesia, desentralisasi sektor kesehatan tidak selalu berdampak baik pada upaya penurunan angka kematian ibu, bayi dan anak balita. Desentralisasi tidak hanya memberi kewenangan pengembangan kebijakan lokal spesifik yang tepat, tetapi juga kebijakan yang tidak mendukung kebijakan nasional sehingga berdampak pencapaian yang rendah. Penelitian ini bertujuan mengetahui efektivitas desentralisasi kesehatan dalam mendorong pemerintah daerah menurunkan angka kematian ibu dan bayi. Penelitian ini menggunakan metode kualitatif wawancara semi terstruktur, observasi, dan diskusi kelompok terarah pada informan kunci yang terlibat dalam penyusunan dan pelaksanaan kebijakan daerah. Tiga kabupaten dipilih secara purposif berdasarkan expert judgement meliputi Kabupaten Pasuruan, Kabupaten Takalar dan Kabupaten Kupang. Kebijakan desentralisasi ditemukan bukan saja memberikan kewenang pelayanan kesehatan, tetapi juga menuntut kreativitas penyusunan kebijakan kesehatan. Tiga kabupaten tersebut ternyata mampu membuat kebijakan kesehatan yang menurunkan angka kematian ibu dan bayi. Di setiap daerah, ditemukan inovasi kebijakan yang mengarah pada perbaikan sistem pelayanan kesehatan ibu dan bayi. Pemerintah pusat perlu mendorong pemerintah daerah untuk berinovasi mengembangkan kebijakan kesehatan sehingga target MDGs bidang kesehatan pada tahun 2015 dapat tercapai.
\end{abstract}

Kata kunci: Angka kematian ibu, angka kematian bayi, kebijakan daerah

\section{Abstract}

In Indonesia, health sector desentralization does not always show good effect reduction measure of infant, maternal and under five children mortality. Local government can make appropriate local spesific health policy, but not always appropriate to national policy, that effect on low coverage. The objective of this study is to analyzes the rule of local policies in reducing maternal and infant mortality rate in Indonesia. The approach used is qualitative research with semi-structured interviews to key informants involved in the preparation and implementation of local policies, making direct observation and Focus Group Discussion (FGD). Three districts were selected purposively based on expert judgment are Pasuruan District, Takalar District and Kupang District. The results showed that decentralization gives local governments the authority to conduct health services and local government demanded creativity in formulating health policy. The three districts were able to make health policy related to reducing maternal and infant mortality. This policy is effective to a decrease in maternal and infant mortality rates in the three districts. Although found in every area of innovation policy but its direction is towards the improvement of the health care system for mothers and babies. Therefore, the central government needs to encourage local governments to undertake innovative health policies mainly to decrease maternal and infant mortality rates in order to achieve the MDGs health targets to be achieved by 2015 .

Keywords: Maternal mortality rate, infant mortality rate, local policies

\section{Pendahuluan}

Angka kematian ibu, bayi dan balita di Indonesia masih tergolong tinggi dan merupakan salah satu masalah utama kesehatan. ${ }^{1-3}$ Berdasarkan Tujuan Pembangunan Milenium (Millenium Development Goals) 2015, target Indonesia menurunkan angka kematian ibu (AKI), angka kematian bayi (AKB) dan angka kematian balita (AKABA) masing-masing menjadi 102 per 100.000 ; 23 per 100.000 dan 32 per 100.000 kelahiran hidup. Berdasarkan Survei Demografi Kesehatan Indonesia (SDKI) tahun 2007, AKI, AKB dan AKABA tersebut masing-masing masih 228; 34 dan 44 per

Alamat Korespondensi: Wiko Saputra, Perkumpulan Prakarsa Indonesia, Jl. Rawa Bambu I Blok A No. 8E Rt. 010 Rw. 06 Pasar Minggu Jakarta Selatan 12520, Hp.082124666788, e-mail: wiko@theprakarsa.org 
100.000 kelahiran hidup. Angka kematian bayi (AKB) dan AKABA dalam lima tahun terakhir menunjukkan kecenderungan yang menurun, tetapi AKI diperkirakan tidak dapat mencapai target MDGs. ${ }^{4-6}$

Desentralisasi sektor kesehatan di Indonesia berdampak baik sekaligus berdampak buruk pada pembangunan kesehatan, khususnya pada program penurunan AKI, AKB, dan AKABA. Desentralisasi memungkinan pemerintah daerah membuat program pembangunan kesehatan spesifik yang sesuai dengan kebutuhan setempat. ${ }^{7}$ Namun, desentralisasi juga memberi peluang pada pemerintah daerah melaksanakan program pembangunan kesehatan yang tidak sesuai kebijakan pembangunan kesehatan nasional sehingga berdampak pencapaian outcome kesehatan nasional yang tidak merata. Di beberapa daerah, bahkan menjadi lebih buruk dibandingkan dengan sistem pemerintahan sentralistik. ${ }^{8}$

Beberapa kabupaten di Indonesia mempunyai regulasi daerah yang secara spesifik mengatur upaya penurunan AKI, AKB, dan AKABA. Pada tahun 2008, Kabupaten Pasuruan, Jawa Timur menetapkan Peraturan Daerah, Peraturan Bupati dan Peraturan Desa tentang kesehatan ibu dan bayi baru lahir yang berhasil menurunkan berbagai angka indikator kesehatan ibu anak dan balita. Bahkan pada tahun 2012, mendapatkan MDGs Award dari Kantor Utusan Khusus Presiden RI untuk MDGs. Kabupaten Takalar berupaya menurunkan angka kematian ibu dan bayi dengan mengeluarkan Perda No. 2 Tahun 2010 tentang kemitraan bidan dan dukun yang telah mencapai nol angka kematian ibu sehingga menjadi daerah percontohan bagi daerah lain. Sementara itu, Kabupaten Kupang juga mengeluarkan Perbup No. 16 Tahun 2010 tentang Percepatan Pelayanan Kesehatan untuk Ibu dan Anak setelah program Revolusi KIA dari pemerintah provinsi NTT tahun 2009 tetapi masih jauh dari target penurunan yang ditargetkan.

Upaya penurunan angka kematian ibu, bayi dan balita di beberapa kabupaten tersebut menunjukkan inovasi kebijakan daerah di bidang kesehatan. Pada tiap kebijakan yang dikeluarkan, ada yang berhasil dan kurang berhasil, harus menghadapi tantangan serius meningkatkan outcome kesehatan penduduk di wilayah tersebut. Studi ini dilakukan untuk mempelajari peran kebijakan daerah dalam menurunkan angka kematian ibu dan anak di Kabupaten Pasuruan, Kabupaten Takalar dan Kabupaten Kupang. Studi ini penting untuk pembelajaran bagi daerah lain di Indonesia yang sedang berupaya mempercepat pencapaian target MDGs pada tahun 2015.

\section{Metode}

Penelitian dengan metode kualitatif ini mengumpulkan data dengan wawancara semi-terstruktur pada informan kunci yang terlibat dalam penyusunan dan pe- laksanaan berbagai kebijakan daerah yang dikaji. Selain itu, peneliti juga melakukan pengamatan langsung dan mendokumentasikan dalam bentuk foto. Focus Group Discussion (FGD) juga dilakukan untuk berbagai kelompok responden berdasarkan kelompok profesi dan wilayah kerja, yang dilaksanakan jika ada kebutuhan mendapatkan informasi kelompok untuk isu tertentu dan mendapatkan pandangan berbagai perspektif. Pengkajian dokumen dilakukan terhadap data profil wilayah, kebijakan umum wilayah dan dokumen kebijakan.

Tiga kabupaten dipilih secara purposif berdasarkan expert judgement, pantauan media dan representasi kewilayahan. Indonesia bagian barat adalah Pulau Jawa, Indonesia bagian tengah adalah Pulau Sulawesi, dan Indonesia bagian timur adalah Pulau Timor. Hal tersebut dijadikan pertimbangan, untuk memudahkan secara logistik dan mengakses pembuat dan pelaksana kebijakan serta mengurangi waktu untuk membangun rapport dengan mereka.

Responden di setiap daerah dipilih berdasarkan relevansi yang bersangkutan dengan kebijakan dan program. Jumlah responden di seluruh wilayah studi adalah 43 orang. Pemilihan responden kunci dilakukan secara purposif di ketiga kabupaten, terutama untuk pengambil kebijakan tingkat kabupaten pada pihak eksekutif dan legislatif. Di setiap kabupaten, dipilih dua puskesmas sebagai satuan organisasi yang menyelenggarakan pelayanan kesehatan tingkat pertama kepada perorangan dan masyarakat, Puskesmas juga berperan sebagai Unit Pelaksana Teknis Dinas (UPTD) bidang kesehatan di setiap kabupaten/kota sehingga mempunyai posisi dan peran yang sangat strategis dalam pembangunan kesehatan.

Di Kabupaten Pasuruan, pemilihan puskesmas yang dikaji direkomendasikan oleh Dinas Kesehatan kabupaten. Di Kabupaten Takalar, puskesmas dipilih berdasarkan status sebagai puskesmas percontohan dan nonpercontohan, sedangkan di Kabupaten Kupang pemilihan berdasarkan rekomendasi dan diskusi dengan Dinas Kesehatan kabupaten dan penyandang dana internasional yang mempunyai data yang lebih lengkap. Kepala puskesmas memilih responden bidan, dukun, kader dan aktivis LSM dalam wilayah kerja dengan metode snowball.

Data hasil wawancara kemudian di transkripsi menjadi berkas dokumen dan dikelompokkan menurut kelompok pertanyaan-pertanyaan dalam panduan wawancara. Dari matriks hasil wawancara dan FGD, diambil tema-tema yang sering muncul dan berulang kemudian dikategori ulang menurut kategorisasi yang baru, tanpa memperhatikan wilayah. Dari sini dihasilkan sintesis hasil penelitian untuk keseluruhan wilayah. Sedangkan studi kasus di tiap wilayah dilakukan secara lebih deskriptif berdasarkan hasil wawancara dan FGD. 


\section{Hasil}

\section{Kasus di Kabupaten Pasuruan}

Sekitar tahun 2003, Kementerian Kesehatan memperkenalkan perencanaan kesehatan kota/kabupaten melalui pendekatan District Team Problem Solving (DTPS) yang merupakan bagian strategi Making Pregnancy Saver (MPS) yang dikembangkan oleh World Health Organization (WHO). Pendekatan ini kemudian dikembangkan sesuai dengan konteks Indonesia sehingga pada tahun 2008 menjadi acuan dalam perencanaan kesehatan ibu dan anak di Indonesia, yang lebih dikenal sebagai DTPS - Kesehatan Ibu dan Bayi Baru Lahir dan Anak (KIBBLA). Pedoman DTPS - KIBBLA telah didiseminasikan ke seluruh kabupaten/kota pada tahun 2008 , tetapi belum dijadikan kebijakan lokal di semua daerah.

Pada tahun 2008, di Jawa Timur, Pasuruan adalah kabupaten ketiga yang mempunyai Peraturan Daerah KIBBLA setelah Kabupaten Malang dan Kabupaten Madiun. Pada tahun 2008, angka kematian ibu di Pasuruan berada pada rasio 99,24 per 100.000 kelahiran hidup. Kasus gizi buruk balita tahun 2007 mencapai 3,18 $\%$, dan dianggap cukup tinggi oleh pemerintah daerah. Sedangkan pertolongan persalinan oleh tenaga kesehatan tahun 2008 hanya mencapai 87,12\%, artinya pertolongan persalinan oleh oleh nontenaga kesehatan masih sekitar 12,88\%. Dalam kondisi inilah Dinas Kesehatan mengawali inisiatif konsep pelaksanaan pelayanan kesehatan ibu dan bayi yang terintegrasi, baik secara lintas program maupun lintas sektor.

Peraturan Daerah Nomor 2 Tahun 2009 tentang KIBBLA mulai masuk dalam pembahasan di DPRD pada tahun 2008. Senada dengan pihak eksekutif, DPRD perlu memunculkan peraturan daerah ini karena angka kematian ibu dan bayi dianggap masih tinggi. Aktor yang ikut berperan aktif dalam membahas peraturan daerah ini adalah Pokja KIBBLA, yang terdiri dari unsur LPK NU (Lembaga Pelayanan Kesehatan Nahdlatul Ulama), Muslimat NU dan Fatayat NU, Muhammadiyah serta dari beberapa LSM perempuan yg peduli dengan kesehatan.

DPRD Kabupaten Pasuruan akhirnya mengesahkan Perda KIBBLA pada tanggal 13 Januari 2009. Setelah pengesahan Perda, bupati mengeluarkan aturan teknis dalam bentuk Peraturan Bupati Nomor 6 Tahun 2010 tentang Pedoman Umum Penyelenggaraan KIBBLA di Pasuruan yang mengatur pelaksanaan Perda KIBBLA ini mulai dari tingkat kabupaten, kecamatan, hingga desa dengan adanya peraturan-peraturan desa.

Health Support Program (HSP) dari USAID (United States Agency for International Development) yang pada saat itu juga bekerja di wilayah Jawa Timur, tertarik untuk mendukung Perda ini. Pada fase perpanjangan HSP (tahun 2009-2010), niat kerja sama itu dituangkan dalam naskah perjanjian rencana kerja antara Pemerintah Kabupaten Pasuruan dengan HSP tentang Pelaksanaan
Program Pembangunan Kesehatan Ibu dan Bayi Baru Lahir dan Anak (KIBBLA). Program ini pada dasarnya melakukan fungsi perbantuan teknis (technical assistance) untuk mendampingi program kesehatan ibu dan anak di Kabupaten Pasuruan. Pelaksanaan kegiatan ini melibatkan beberapa aparat pemerintahan mulai dari Bupati sampai kepala Desa, unsur organisasi masyarakat, agama dan organisasi profesi (IBI dan IDI), BKKBN, serta tenaga kesehatan yang meliputi bidan, perawat dan dokter serta kader kesehatan. Pembentukan Tim KIBBLA dilakukan ditingkat kabupaten dan kecamatan.

Menurut responden, dampak kebijakan KIBBLA ini antara lain meliputi; perubahan perilaku pemeriksaan tenaga kesehatan, peningkatan pengetahuan kader kesehatan akibat berbagai kegiatan pengembangan kapasitas. peningkatan cakupan ibu hamil yang memeriksakan diri sebelum melahirkan dan penurunan AKI dan AKB. Sebelum program KIBBLA, di Kabupaten Pasuruan, masih banyak ibu yang melalukan periksaan tenaga profesional setelah usia hamil lebih dari tiga bulan. Setelah program KIBBLA berjalan, banyak memeriksakan diri secara teratur dan melahirkan dengan pertolongan bidan serta memanfaatkan fasilitas kesehatan. Kebiasaan memeriksakan kehamilan pada dukun juga berkurang, lebih banyak yang memilih tenaga kesehatan.

Setelah mendapat berbagai pelatihan, petugas puskesmas dan kader kesehatan menjadi lebih percaya diri dalam memberikan informasi dan penyuluhan kepada masyarakat. Sebagai ujung tombak di masyarakat, perlu memperhatikan kebutuhan para kader tersebut. Jika tidak, mereka tidak merasa menjadi bagian penting dari program/kebijakan. Hal tersebut terlihat pada peningkatan cakupan indikator K1 dan K4. Cakupan indikator K1 pada tahun 2009 (98,77\%) dan pada tahun 2009 meningkat menjadi 99,98. Cakupan indikator K4 juga meningkat dari tahun 2009 (90,07\%) dan menjadi tahun 2011 (92,06\%). Pencapaian K1 dan K4 yang semakin tinggi, semakin mengurangi kelaianan kehamilan yang tidak terdeteksi sehingga terjadi penurunan resiko kematian ibu dan bayi.

Dampak penting pelaksanaan program KIBBLA terlihat pada tren penurunan angka kematian ibu dan bayi pada periode 2010 - 2011. Angka kematian ibu masih fluktuatif, yaitu dari 87,61\100.000 KH pada tahun 2009, menjadi 108,98\100.000 KH pada tahun 2010 dan menjadi 96,34\100.000 pada tahun 2011. Perlu dicermati, kemajuan pembangunan dalam berbagai aspek seperti infrastruktur, ketersediaan air bersih dan penyebaran informasi dan pengetahuan masyarakat sejalan dengan penurunan kematian ibu.

\section{Kabupaten Takalar}

Pada tahun 2006, di Kabupaten Takalar ditemukan 
enam kasus kematian ibu bersalin akibat pendarahan dan eklamsia yang tidak ditolong oleh tenaga medis. Jumlah kematian tersebut menyebabkan rasio AKI Kabupaten Takalar menjadi 300 per 100.000 kelahiran hidup, angka tersebut masih sangat jauh dari target pencapaian MDGs sehingga menjadi keprihatinan pemerintah Kabupaten Takalar. Hal terjadi karena masih banyak pertolongan persalinan yang dilakukan oleh dukun.

Konsolidasi kemudian diadakan dengan berbagai pihak, baik dari jajaran eksekutif seperti Bupati, Wakil Bupati dan Sekretaris Daerah beserta Dinas Kesehatan dan jajaran di bawahnya maupun dengan pihak legislatif (DPRD). Menyambut positif semua pihak di pemerintahan daerah sehingga dinas kesehatan (dinkes) mendapatkan dukungan kuat untuk memastikan perlunya implementasi program Kemitraan Bidan dan Dukun (KBD) untuk diperkuat dalam bentuk peraturan daerah. Dinkes Takalar mengajukan proposal ke (United Nations of Children's Fund) UNICEF yang kemudian disetujui. Program KBD kemudian diujicobakan pada tahun 2007 di lima puskesmas yaitu Puskesmas Polongbangkeng Utara, Puskesmas Toata, Puskesmas Ko'mara di Kecamatan Galesong Utara, dan Puskesmas Galesong dan Puskesmas Bontomarannu di Kecamatan Galesong Selatan. Dalam perkembangannya, program ini dikembangkan ke semua puskesmas.

Langkah selanjutnya yang dilakukan oleh Pemda Kabupaten Takalar adalah meningkatkan kapasitas bidan dan dukun melalui pelatihan dan kemitraan. Pada pertengahan tahun 2007 indikator kematian ibu mulai menurun menjadi tiga orang. Pemerintah daerah merasa perlu ada kekuatan hukum untuk menjamin keberlanjutan hasil tersebut. Oleh karena itu, pada tahun 2008 Bupati Takalar mengeluarkan SK Bupati Nomor 01 Tahun 2008 tentang KBD. Setelah melewati proses konsolidasi dengan para pemangku kepentingan, pada tahun 2009 dibuat Rancangan Peraturan Daerah KBD yang difasilitasi oleh UNICEF. Rancangan peraturan daerah tersebut mengatur hak, kewajiban, tugas, wewenang dan sanksi dalam kemitraan bidam dan dukun bayi.

Rancangan peraturan daerah ini ditetapkan menjadi Perda Nomor 02 Tahun 2010 oleh DPRD pada tanggal 29 Januari 2010. Dalam Pasal 3 Perda ini, disebutkan bahwa kemitraan bidan dan dukun bayi (KBD) bertujuan untuk mendayagunakan Dukun Bayi sebagai pendamping spiritual untuk melakukan komunikasi yang terarah sesuai dengan kebutuhan ibu hamil, melahirkan dan nifas, serta membantu bidan dalam semua proses sesuai dengan kemampuannya untuk meningkatkan cakupan pertolongan persalinan bidan dalam rangka menurunkan angka kematian ibu (AKI) akibat kehamilan, melahirkan dan nifas serta mendorong kemandirian masyarakat untuk berperilaku hidup bersih dan sehat. Keberadaan Perda Kemitraan Bidan dan Dukun di Kabupaten
Takalar telah memberikan dampak baik bagi masyarakat maupun bagi pemerintah setempat, antara lain penurunan $\mathrm{AKI}$, peningkatan kepercayaan diri tim KBD, perubahan perilaku masyarakat.

Angka kematian ibu di Kabupaten Takalar mengalami penurunan dari 300/100.000 kematian hidup pada tahun 2006 menjadi nol pada tahun 2012. Hal yang sama terjadi pada indikator lain seperti cakupan pemeriksaan (K1, K4) dan persalinan yang ditolong tenaga kesehatan. Angka K1 Kabupaten Takalar adalah 23\% pada tahun 2006 (sebelum KBD), dan terus berangsur meningkat hampir 5 kali lipat sehingga mencapai $105 \%$ pada tahun 2012. Angka K4 meningkat dari $24,37 \%$ pada tahun 2006 menjadi $97 \%$ pada tahun 2012, persalinan ditolong tenaga kesehatan meningkat dari $81,52 \%$ pada tahun 2010 menjadi 96,4\% pada tahun 2011.

Kepercayaan diri tim Kerja Kemitraan Bidan dan Dukun (KBD), dalam menjalankan tugas meningkat karena ada jaminan hukum. Tim KBD mendapat jaminan perlindungan secara hukum di lapangan dengan keberadaan Peraturan daerah KBD sehingga mereka tidak ada lagi keraguan dalam menjalankan tugas di lapangan. Bidan semakin mendapatkan kepercayaan dari masyarakat dan dukun tetap tidak kehilangan pekerjaan, bahkan mendapatkan tambahan penghasilan Rp50.000 setiap membantu persalinan. Dukun merasakan penambahan pengetahuan tentang metode pertolongan persalinan yang aman. Perubahan perilaku yang diamati pada tingkatan masyarakat terlihat pada para ibu baik hamil, melahirkan, dan mempunyai bayi dan balita meliputi kebiasaan pemeriksaan kehamilan, melahirkan, dan kesadaran terhadap peranan tenaga medis. Kebiasaan warga untuk mendapat imunisasi juga merupakan dampak perilaku masyarakat yang disebabkan oleh peraturan daerah tersebut.

Kabupaten Takalar menjadi salah satu tempat belajar program KBD di Indonesia. Kementerian Kesehatan RI menetepkan Kabupaten Takalar sebagai salah satu daerah percontohan KBD di Indonesia. Kini kabupaten tersebut menjadi daerah yang sering dikunjungi daerah lain yang ingin belajar. Pemerintah daerah Kabupaten Takalar mendapatkan insentif bukan hanya dalam bentuk material juga tapi apresiasi dari pemerintah daerah lain dan Pemerintah Pusat.

\section{Kasus Kabupaten Kupang}

Di Provinsi NTT, pencapaian target-target MDG's mengalami banyak hambatan, antara lain karena tingkat kemiskinanyang tinggi, infrastruktur yang buruk dan kualitas SDM yang rendah. Selain itu, kebiasaan lokal yang dijalankan oleh ibu hamil juga sering menghambat upaya peningkatan kesehatan ibu dan anak baru lahir seperti asupan makanan kurang bergizi dan kebiasaan 'panggang' ibu hamil yang berbahaya. 
Untuk percepatan pencapaian target MDG's kesehatan maternal, pemerintah provinsi merespons dengan program Revolusi KIA. Program ini dilandasi Peraturan Gubernur NTT Nomor 42 tahun 2009 tentang Revolusi KIA yang menekankan dua bidang intervensi meliputi sisi pemerintah/swasta sebagai penyedia pelayanan kesehatan dan sisi masyarakat sebagai yang membutuhkan pelayanan kesehatan. Proses penyusunan peraturan gubernur tersebut dilakukan sejak pertengahan tahun 2008 hingga Juli 2009 yang melibatkan aktor lintas sektoral bersama sektor terkait dan donor luar negeri. Upaya tersebut ditindaklanjuti dengan penyusunan rencana kegiatan setiap program di Dinas Kesehatan Provinsi NTT serta sosialisasi kepada berbagai pihak di tingkat provinsi dan kabupaten/kota. Upaya sosialisasi tersebut didukung oleh Australia Indonesia Partnership for Maternal and Neonatal Health (AIPMNH AusAID). Upaya percepatan penurunan kematian ibu melahirkan dan bayi baru lahir melalui persalinan di fasilitas pelayanan kesehatan yang memadai selama 24 jam tersebut mengadopsi pola di Srilanka, Malaysia dan Singapura.

Merespons peraturan gubernur tersebut, pemerintah Kabupaten Kupang mengeluarkan Peraturan Bupati (Perbup) Nomor 16 Tahun 2010 tentang Percepatan Pelayanan KIA yang mengupayakan proses pemeriksaan kehamilan dan pertolongan persalinan di fasilitas kesehatan oleh tenaga kesehatan. Kabupaten Kupang melakukan upaya Revolusi KIA dengan membentuk Tim Penyusun Regulasi Perbup Revolusi KIA meliputi Bagian Hukum, Badan Perencanaa dan Pembangunan Daerah, dan Dinas Kesehatan sebagai leading sector. Pemerintah kabupaten juga mendapat juga dukungan dari AusAID. Berbagai program mendukung percepatan pelayanan KIA dilaksanakan dengan dukungan AIPMNH yang ikut menginisiasi kelahiran draf rancangan peraturan daerah KIBBLA. Donor lain seperti ADB juga ikut berperan secara tidak langsung, dukungan percepatan pelayanan KIA tersebut dapat dilihat pada program NICE.

Dalam Perbup Nomor 16 tahun 2010, bupati bertanggung jawab melakukan pembinaan dan pengawasan terhadap seluruh kegiatan terkait. Kepala Dinas Kesehatan Kabupaten Kupang bertugas mengoordinasi semua kegiatan dengan pelayanan kesehatan ibu dan bayi yang dilakukan oleh Pemda dan swasta. Koordinasi lintas sektor melibatkan dinas kesehatan, puskesmas, rumah sakit, Bappeda, BPMD dan pihak kecamatan serta desa.

Puskesmas leluasa melakukan berbagai inisiatif untuk percepatan pelayanan kesehatan Ibu dan Anak karena dana operasional kesehatan masyarakat dari pusat langsung dikelola oleh puskesmas dan peran dinas kesehatan lebih pada fungsi koordinatif. Kebijakan percepatan pelayanan KIA terindikasi antara lain ber- dampak. Peningkatan cakupan ibu yang memeriksakan kehamilan, terlihat pada peningkatan cakupan indikator K1 dan K4. Pada tahun 2008, cakupan K1 sekuitar 93,47\% meningkat menjadi 96,53\% pada tahun 2011 . Cakupan indikator K4, tahun 2008 adalah sekitar 75,07\% meningkat menjadi 86,06\% pada tahun 2011 .

Pada tahun 2010 dan 2011, di Kabupaten Kupang, terjadi penurunan kematian bayi, balita dan ibu, kematian bayi menurun dari 91 kasus menjadi 54 kasus, kematian ibu hanya berkurang satu kasus dan kematian balita berkurang dari 24 kasus menjadi 17 kasus Namun, peneliti kesulitan mendapatkan data yang akurat tentang rasio AKI, AKB dan AKBA tersebut karena kesulitan mendapatkan data tentang jumlah kelahiran hidup.

\section{Pembahasan \\ Aspek Kebijakan}

Pemerintah, khususnya pemerintah pusat melakukan berbagai upaya untuk menurunkan angka kematian ibu dan bayi sejak tahun 1990-an. ${ }^{6}$ Strategi Making Prenancy Safer (MPS) yang dikembangkan tahun 2008 melalui DTPS-KIBBLA menjadi salah satu alasan kebijakan DTPS-KIBBLA di Pasuruan pada tahun 2008. Kementerian Kesehatan Republik Indonesia juga menerbitkan Pedoman Kemitraan Bidan dan Dukun, pada tahun 2008, berdasarkan kegiatan yang dilaksanakan di Kabupaten Takalar dan Kabupaten Subang sebelumnya. ${ }^{9}$ Pemerintah Pusat mengharapkan berbagai program tersebut dijadikan kebijakan di kabupaten/kota di seluruh Indonesia, tetapi belum semua Pemda membuat turunan kebijakan tersebut.

Di Kabupaten Kupang, DPRD berperan sangat terbatas dalam kebijakan kesehatan ibu dan anak. Menurut DPRD, saat ini peraturan daerah tentang pelayanan KIA belum prioritas di daerah tersebut. Untuk mengatasi masalah pelayanan KIA tersebut, pemda provinsi dan kabupaten, membuat peraturan gubernur dan peratran bupati. Di Kabupaten Pasuruan, inisiator awal adalah dinas kesehatan, tetapi penggerak utama penyusunan peraturan daerah adalah Pokja KIBBLA yang dimotori oleh anggota DPRD yang juga adalah tokoh yang berpengaruh. Di Kabupaten Takalar, DPRD yang sangat kooperatif mengupayakan program KBD menjadi Peraturan Daerah, melihat manfaat dan dampak program tersebut dalam penurunan AKI di Takalar.

Di Kabupaten Takalar, memilih pendekatan kultural untuk para dukun. Hal tersebut juga dilakukan di Kabupaten Pasuruan dan Kabupaten Kupang, tetapi tidak dalam bentuk perda yang mengikat seperti di Kabupaten Takalar, sehingga manfaat masif tidak terlihat di seluruh kabupaten. Pendekatan kultural tersebut jugalah yang dilakukan di Kabupaten Pasuruan, melalui Pokja KIBBLA dengan motor utama ormas-ormas NU seperti Fatayat, Muslimat dan LPK NU. Di Kabupaten 
Takalar, pihak eksekutif yang diwakili Dinas Kesehatan dan Bappeda dan berbagai stakeholder meliputi tokoh masyarakat, organisasi profesi seperti IBI dan LSM yang peduli kesehatan juga dilibatkan dalam forum Dewan Kesehatan, pada tahun 2005, berdasarkan SK Bupati. Di Kabupaten Kupang, sebaliknya proses agenda setting masih sangat bersifat top down karena kebijakan kabupaten ditetapkan lebih karena kewajiban menurunkan peraturan gubernur tentang revolusi KIA.

Di Kabupaten Pasuruan, secara khusus menyebutkan perlu peraturan desa (perdes) untuk menindaklanjuti peraturan daerah (perda). Hampir semua desa disusun Perdes KIBBLA yang menyatakan bahwa desa terikat melakukan pengelolaan dan penggalangan dana bagi kontribusi dipelayanan KIBBLA tingkat desa. Hal tersebut berbeda dari Kabupaten Takalar dan Kabupaten Kupang yang baru melakukan secara sporadis. Peraturan desa memastikan pengawasan dan kontrol di tingkat desa.

Meskipun banyak program KIA yang didanai dari Pemerintah Pusat, termasuk BOK dan Jampersal, pada Perda KIBBLA Kabupaten Pasuruan, dinyatakan secara jelas bahwa anggaran KIBBLA diambil dari APBD 1. Di Kabupaten Takalar dan Kabupaten Kupang, dengan kapasitas fiskal daerah yang lebih rendah, Pemda lebih banyak memanfaatkan dana-dana program dari Pemerintah Pusat. Khusus Kabupaten Kupang, dengan angka kemiskinan dan indikator kesehatan yang lebih buruk, banyak donor yang memberikan bantuan. Dana bantuan tersebut bahkan lebih dari anggaran Pemda.

Komitmen Bupati Pasuruan untuk menjadikan bidang kesehatan sebagai prioritas diterjemahkan dalam kenaikan anggaran kesehatan. Pada tahun 2012, anggaran kesehatan dalam APBD disamakan dengan anggaran pendidikan, sekitar 20\% dari total APBD. Dana khusus untuk Program KIA meningkat dari 6\% pada tahun 2009 menjadi $16 \%$ pada tahun 2010 . Anggaran pemerintah pusat dan provinsi dikelola oleh puskesmas secara efektif. Proporsi pembiayaan Ponkesdes di Kabupaten Pasuruan adalah 50:50 dari APBD provinsi dan kabupaten. Kader Asuh, yang merupakan program inovasi Puskesmas Ngempit di Pasuruan didukung oleh Dinas Kesehatan Kabupaten Pasuruan dengan bantuan dana transportasi Rp 10 ribu setiap bulan.

Selain anggaran pemerintah pusat seperti BOK, Jamkesmas, Jampersal, Pemerintah Kabupaten Takalar juga mengalokasikan anggaran khusus untuk program KIA. Pada tahun 2011, alokasi anggaran perawatan berkala ibu hamil dari keluarga kurang mampu sebesar Rp 111 juta dari APBD. Pada tahun 2012, turun menjadi $60 \%$ karena Jampersal yang bersifat universal coverage. Biaya operasional per dukun sebesar Rp 50 ribu diambil dari Jampersal untuk mengantar satu orang ibu melahirkan. Insentif kader posyandu sebesar Rp 10 ribu per bulan diambil dari line budget transportasi non-PNS dalam BOK dan komponen transport dalam anggaran aktivitas program Dinas Kesehatan. Selain dana dari pusat, Provinsi Sulsel punya program kesehatan gratis, dengan skema pembiayaan kesehatan di APBD meliputi $40 \%$ dari APBD provinsi, dan $60 \%$ dari kabupaten.

Di Kabupaten Kupang, alokasi anggaran sektor kesehatan masih sangat rendah, hanya sekitar $8 \%$ dari APBD kabupaten tahun 2010. Khusus untuk anggaran KIA, hanya sekitar 0,007\% dari APBD. Namun, seperti di kedua daerah lain, pemanfaatan dana-dana dari pusat menjadi andalan puskesmas dan tenaga kesehatan untuk melakukan tugas-tugas mereka. Hampir seluruh responden di Kabupaten Kupang mengangkat isu keterbatasan anggaran sebagai isu utama dalam penurunan AKI di kabupaten tersebut.

Donor asing seperti HSP-USAID di Kabupaten Pasuruan, UNICEF di Kabupaten Takalar dan AIP MNH di Kabupaten Kupang cukup berpengaruh. Setiap donor terlibat dengan cara dan tingkatan yang berbeda di setiap kabupaten. Di Kabupaten Pasuruan, HSP-USAID belum masuk ketika Perda disahkan, tetapi tertarik mendukung pelaksanaan dengan melakukan berbagai pelatihan dan sistematisasi pendataan kesehatan ibu dan anak serta bantuan teknis yang lain. Di Kabupaten Takalar, UNICEF membantu melakukan pelatihan dan bantuan teknis ke beberapa puskesmas. Sedangkan di Kabupaten Kupang, peran berbagai donor seperti UNICEF, UNFPA, AIP - MNH dan lain-lain cukup besar. Hal yang mencolok dan sama di semua kabupaten adalah bahwa keberhasilan dan kebijakan di daerah tersebut sangat bergantung pada peran kepala puskesmas di tingkat kecamatan.

\section{Aspek Perubahan}

Hampir semua responden menatakan perubahan yang lebih baik, dalam indikator utama seperti cakupan pemeriksaan ibu hamil, pertolongan persalinan yang ditolong tenaga kesehatan dan AKI serta AKB serta perubahan perilaku dan peningkatan pengetahuan. Selama masa intervensi program KBD, peningkatan indikator kuantitatif paling signifikan terjadi di Kabupaten Takalar, karena kebijakan telah diluncurkan sejak lama (2007) sehingga perubahan signifikan dapat diamati dalam jangka waktu lima tahun. Di Kabupaten Pasuruan dan Kupang, perubahan yang diamati umumnya masih sangat lambat karena Perda KIBBLA baru diluncurkan tahun 2009 dan Perbup Percepatan Pelayanan KIA tahun 2010. Indikator seperti K1, K4 dan AKI serta AKB berubah secara lambat. Persalinan ditolong tenaga kesehatan, di Kabupaten Pasuruan dan Takalar terdapat kenaikan signifikan masing-masing 6\% di Kabupaten Pasuruan dan hampir 4 kali lipat di Kabupaten Takalar.

Peningkatan signifikan pada K1, K4 dan persalinan ditolong tenaga kesehatan tersebut menyebabkan kore- 
lasi positif terhadap AKI. Ini sangat jelas pada kasus Kabupaten Takalar, semua kenaikan di atas $100 \%$ menyebabkan AKI dapat ditekan selama tiga tahun berturut-turut pada angka nol. Di Kabupaten Pasuruan, rasio AKI dan AKB terlihat menurun, tetapi tiga tahun sejak Perda KIBBLA diluncurkan, AKI dan AKB belum berubah radikal seperti di Kabupaten Takalar.

Di Kabupaten Takalar dan Kupang ada dampak lain berupa peningkatan rasa percaya diri karena merasa 'terlindungi' payung hukum Perda atau Perbup. Juga mulai terjadi perubahan perilaku masyarakat memeriksakan ke tenaga kesehatan dan di fasilitas kesehatan. Pelaksanaan berbagai kebijakan tersebut secara luas mengubah pandangan dan kepercayaan masyarakat kepada tenaga kesehatan. Perubahan pandangan tersebut bersifat transformatif dan jangka panjang sehingga upaya promosi yang intens dan terus menerus perlu dilakukan kader dan tenaga kesehatan. Tingkat pendidikan ibu berkorelasi positif dengan penurunan kematian ibu dan bayi sehingga dalam jangka panjang pendidikan perempuan juga perlu diperhatikan pemerintah. ${ }^{10,11,12}$

Program KBD yang dilaksanakan di Kabupaten Takalar juga diterapkan di kedua kabupaten lain karena merupakan program dari Kementerian Kesehatan. Karena tidak ditetapkan sebagai peraturan daerah yang mengikat dan masif, dampaknya tidak seradikal seperti di Kabupaten Takalar. Di Kabupaten Pasuruan, perubahan terjadi dalam jangka waktu relatif panjang dan lebih diasosiasikan sebagai akibat logis dari kemajuan pembangunan, termasuk pembangunan infrastruktur.

Pembangunan infrastruktur yang lambat di daerah seperti Kabupaten Kupang, sulit mengharapkan perubahan radikal jangka pendek. Selain itu, di Kabupaten Takalar ada keuntungan lain, jumlah penduduk yang relatif kecil. Masalah yang sama dengan Kabupaten Kupang dihadapi oleh Kabupaten Takalar di pulau-pulau kecil yang membutuhkan infrastruktur yang berbeda dan lebih mahal.

\section{Kesimpulan}

Desentralisasi bidang kesehatan memberi ruang yang besar bagi pemerintah daerah untuk melakukan inovasi pelayanan kesehatan masyarakat. Kewenangan yang besar pada era desentralisasi menuntut pemerintah daerah lebih aktif membuat berbagai kebijakan publik khususnya sektor kesehatan. Di Indonesia, angka kematian ibu dan bayi yang tinggi menunjukan pelayanan kesehatan ibu dan bayi masih relatif rendah. Pemda dituntut berperan aktif mendorong kebijakan kesehatan yang menurunkan angka kematian ibu dan bayi. Kabupaten Pasuruan, Takalar dan Kupang melakukan inovasi kebijakan kesehatan yang berupaya menurunkan angka kematian ibu dan bayi efektif menurunkan angka kematian ibu dan bayi.

\section{Saran}

Keterlibatan stakeholder eksekutif, legislatif dan kelompok masyarakat sipil sangat diperlukan dalam penyusunan kebijakan, mendapatkan masukan berbagai perspektif dan meningkatkan dukungan dan rasa kepemilikan. Perlunya penempatan kepala puskesmas yang kompeten dan kreatif sebagai ujung tombak pengelola kebijakan/program kesehatan. Alokasi anggaran khusus merupakan bentuk political will pemerintah daerah. Berbagai faktor struktural seperti budaya, perilaku hidup sehat masih menjadi penghambat jika tidak ditangani dengan baik.

\section{Daftar Pustaka}

1. Adair T. Child mortality in Indonesia's mega urban regions: measurement, analysis of differentials, and policy implications. 12th Biennial Conference of the Australian Population Association, 2004 Sept 15-17; Canberra, Australia. Canberra: Australian Population Association; 2009.

2. Frankenberg E, Suriastini W, and Thomas D. Can xpanding Access to Basic Healthcare Improve Children's Health Status? Lessons from Indonesia's Midwife in the Village' Programme, Population Studies. 2005; 59 (1): 5-19.

3. Swaminathan S, Matsumoto T, Nugent JB. Midwives and maternal mortality: how effective has Indonesia's village midwife program been? UCSD Conference. Tokyo: University of Tokyo and Western Economic Association; 2008.

4. World Bank. Indonesia health sector review: accelerating improvementent maternal health: why reform is needed. Policy and discussion notes. Jakarta: World Bank; 2010.

5. Kementerian Kesehatan Republik Indonesia. Laporan nasional: riset kesehatan dasar (Riskesdas) 2010. Jakarta: Kementerian Kesehatan Republik Indonesia; 2011.

6. The United Nations of Children's Fund. Maternal and child health [online]. Unicef Indonesia, Issue Briefs, October 2012 [cited 2013 Jan 10]. Available from: www.unicef.org/indonesia/A5_E_Issue _Brief_Maternal_REV.pdf.

7. Simatupang R, Rentanida. Evaluation of decentralization outcomes in Indonesia: analysis of health and education sectors. [Dissertation]. Atlanta: Department of Economics Georgia State University; 2009.

8. Lieberman S, Capuno JJ, Minh HV. Decentralizing health: lessons from Indonesia, the Philippines, and Vietnam. Chapter in Books: East Asia Decentralizes. Washinton DC: World Bank; 2010.

9. Pranata S, Pratiwi LP, Rahanto S. Pemberdayaan masyarakat di bidang kesehatan, gambaran peranan kader posyandu dalam upaya penurunan angka kematian ibu dan bayi di Kota Manado dan Palangkaraya. Bulletin Penelitian Sistem Kesehatan. 2011; 14 (2).

10. Chevalier A, O’Sullivan V. Mother's education and birth weight. Discussion Paper No. 2640 February 2007. Forschungsinstitut zur Zukunft der Arbeit Institute for the Study of Labor; 2007.

11. Akmam W. Women's education and fertility rate in developing countries, with special reference to Bangladesh. Eubios Journal of Asian and International Bioethics. 2002; 12: 138-43.

12. McAlister C, Baskett TF. Female education and maternal mortality: a worldwide survey. Journal Obstetrics Gynaecology of Canada. 2006; 28: 983-90. 